\title{
AQUATIC MACROPHYTE COMMUNITIES OF THE GORGOVA-ISAC-UZLINA AREA (DANUBE DELTA, ROMANIA)
}

Erika SCHNEIDER-BINDER *

\begin{abstract}
* Karlsruhe Institute for Technology - University of Land Baden-Württemberg and Research Center of the Helmholtz Society, Institute for Geography and Geoecology, Department Auen-Institut/Institute for Wetlands Ecology, Josef Street 1, Rastatt, Germany, D-76437, erika.schneider@partner.kit.edu, erika.schb@t-online.de
\end{abstract}

DOI: 10.2478/trser-2018-0018

KEYWORDS: types of channels and lakes, macrophyte communities, quality indicators, ecological gradients, human-induced changes.

\section{ABSTRACT}

With its diversity of water body types, the Danube Delta offers large possibilities for studies of aquatic macrophytes, their ecological requirements, ecological amplitude and communities. Sensitive to changes in water quality and physical parameters due to human intervention in the natural ecological network, aquatic macrophytes are used as quality indicators. Using the example of the system of channels and lakes of the Gorgova-Isac-Uzlina complex and some examples from the neighboring area, the aquatic macrophytes and their communities are presented and discussed in relation to the characteristics of the habitats and the changes of the environment in the course of decades, since human intervention in the delta.

ZUSAMMENFASSUNG: Die Wasserpflanzengesellschaften des Seenkomplexes von Gorgova-Isac-Uzlina (Donau-Delta, Rumänien).

Mit ihrer Vielfalt an Gewässertypen, gibt es im Donau-Delta umfassende Möglichkeiten für Untersuchungen der Gewässer-Makrophyten, ihrer ökologischen Ansprüche und ihrer Pflanzengesellschaften. Da die Gewässermakrophyten auf Änderungen der Gewässergüte und der physikalischen Parameter durch menschliche Eingriffe in das natürliche ökologische Gefüge empfindlich reagieren, werden sie als Qualitätsindikatoren eingesetzt. Am Beispiel des Systems von Fließgewässern und Seen des Gorgova-Isac-Uzlina Komplexes und einigen Beispielen aus benachbarten Gebieten werden die Gewässermakrophyten und ihre Gesellschaften vorgestellt und in Zusammenhang mit ihren Habitaten und deren Veränderungen im Laufe mehrerer Jahrzehnte diskutiert.

REZUMAT: Comunitățile de macrofite acvatice din complexul de lacuri Isac-UzlinaGorgova (Delta Dunării, România).

Datorită diversității tipurilor de corpuri de apă, în Delta Dunării există multiple posibilități pentru cercetarea macrofitelor acvatice, a cerințelor lor ecologice și a comunităților pe care le edifică. Deoarece macrofitele acvatice reacționează sensibil la schimbările calităţii apei și a parametrilor fizici cauzate de impactul uman asupra ecosistemelor naturale, acestea sunt folosite ca indicatori de calitate. Folosind drept exemplu sistemul brațelor Dunării cu rețeaua de canale, gârle și lacuri din zona Gorgova-Isac-Uzlina și a unor arii înconjurătoare, sunt prezentate și discutate macrofitele și fitocenozele în relație cu caracteristicile habitatelor, precum și schimbările mediului în decurs de mai multe decenii. 


\section{INTRODUCTION}

With its diversity and complexity of water body types, the Danube Delta offers large possibilities for studies concerning aquatic macrophytes, their ecological requirements and their communities, as well as the changes in their composition by human induced changes (Hanganu and Constantinescu, 2008; Strat, 2015). Sensitive to environmental factors, aquatic macrophytes can be used as good indicators for the ecological state of water bodies and physical characteristics (Neagu-Godeanu, 1875; Ossterberg and Staraș, 2000; Ellenberg et al., 2002; Schneider, 2009, 2014)

The hydrological regime is the main and deciding ecological factor for ecosystem function to be considered in order to characterize and evaluate the ecological state of different types of water bodies and their macrophyte communities. For a first evaluation the general inundability of the different sites is usually considered. It is represented for the whole Danube Delta in the "Danube Delta's inundability map" with five categories of inundation levels named hydro-grades (Munteanu and Curelariu, 1996), the hydro-grade being the tenth part of the difference between the lowest and the highest registered water level at a measured point (Botzan, 1984). These data offer general information about mean values of water levels over a longer period, without demonstrating a concrete situation for a certain year or season in a year. But for a detailed consideration it is needed to know the yearly water level dynamics, the period of flooding, the duration, height and frequency, consecutiveness of flooding over a number of years, and as well the exchange and circulation of waters from the main branches to the smaller ones in the inner of the delta and the residence time (Gâş̧escu and Driga, 1989; Covaliov et al., 2003; Gâştescu and Ştiucă, 2008; Schneider, 2009). All these mentioned factors are crucial for the macro- and microhabitat ecological development and diversity and are varying greatly between the years. This fact is clearly visible, if we compare the row of water level changes from different years measured on the gauge Tulcea (data researched at the Danube Delta Institute Tulcea) and below exemplified on the water level changes from two different years, one with extremely high and one with extremely low water levels measured at gauge Tulcea (Fig. 1).

As a consequence of hydro-technical works in the second half of the 20th century, transformation of wetlands in reed-harvesting polders as well for agricultural and forestry purposes, the structure of the water network has suffered many changes. The measures have affected the relation between main branches and the water network, i.e. channels and lakes in the inner part of the delta (Neagu-Godeanu, 1975; Gâştescu and Driga, 1989; Gâştescu and Ştiucă, 2008). A large number of natural channels disappeared and other artificial new canals arose. With the increased connectivity between the main branches and the inner part of the delta, more unfiltered water entered directly into the system. Due to these conditions an increased eutrophication became visible by changes in the macrophyte communities' composition as well the abundance-dominance relation of characteristic water macrophytes.

The eutrophication has been subject to a number of studies (Oosterberg and Staraş 2000) and is regularly monitored by the researchers of the Danube Delta National Institute Tulcea. To exemplify the changes to the water macrophytes communities, the area of GorgovaIsac-Uzlina situated in the morphogenetic type of the depressions area of the Fluvial Delta (Gâş̧escu and Ştiucă, 2008) between the Sulina and Sfântul Gheorghe branches was selected but also data from area north of the Sulina Branch, taking part of the depressions area of the fluvial Delta (Lopadna, Eracle), have been included. Also for comparison older data from the 1960s and 1970s (Neagu-Godeanu, 1973, 1975) - natural and transformed area of the Danube Delta - have been taken into consideration. 


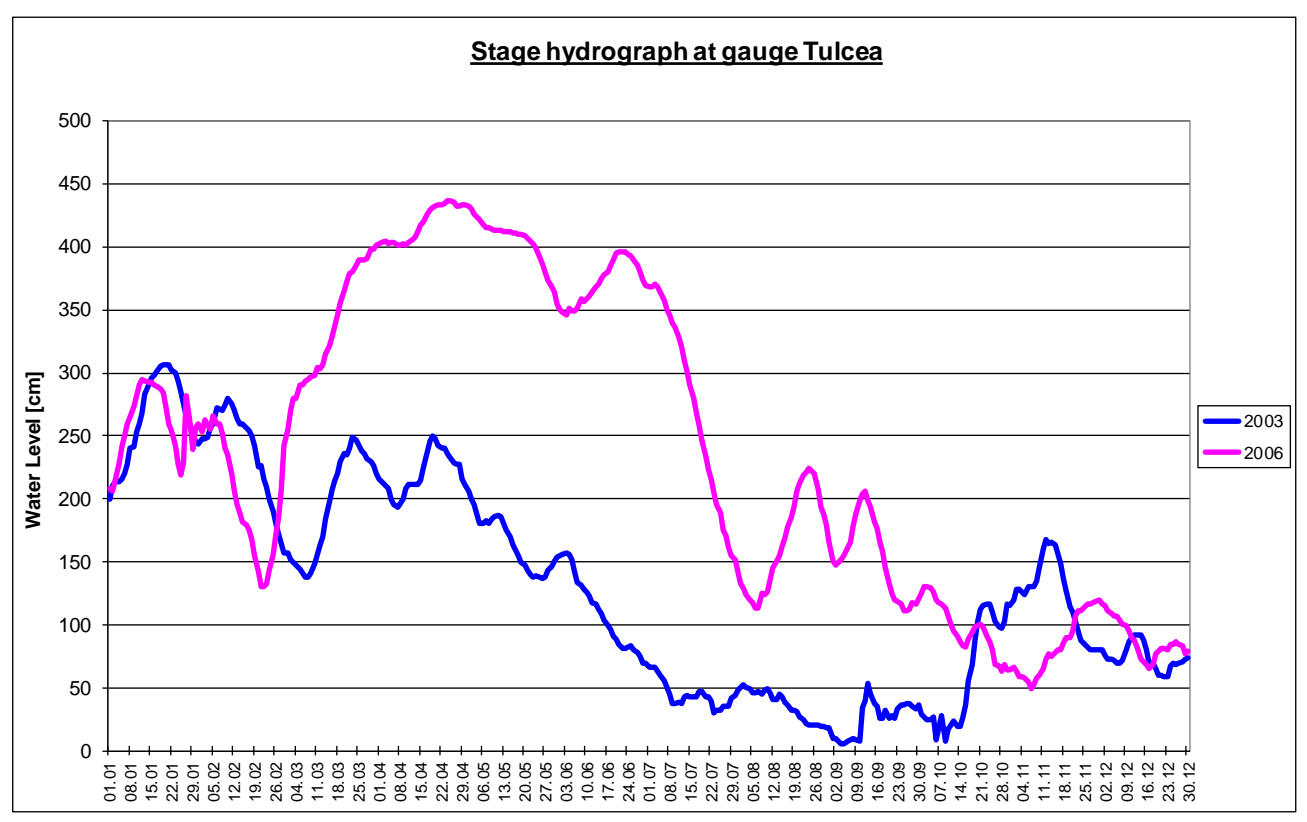

Figure 1: Stage hydrograph of the Danube at gauge Tulcea for the years 2003 with generally low water levels, and 2006 with high water levels during the vegetation period (hydrological data from the Danube Delta National Institute in Tulcea/Romania).

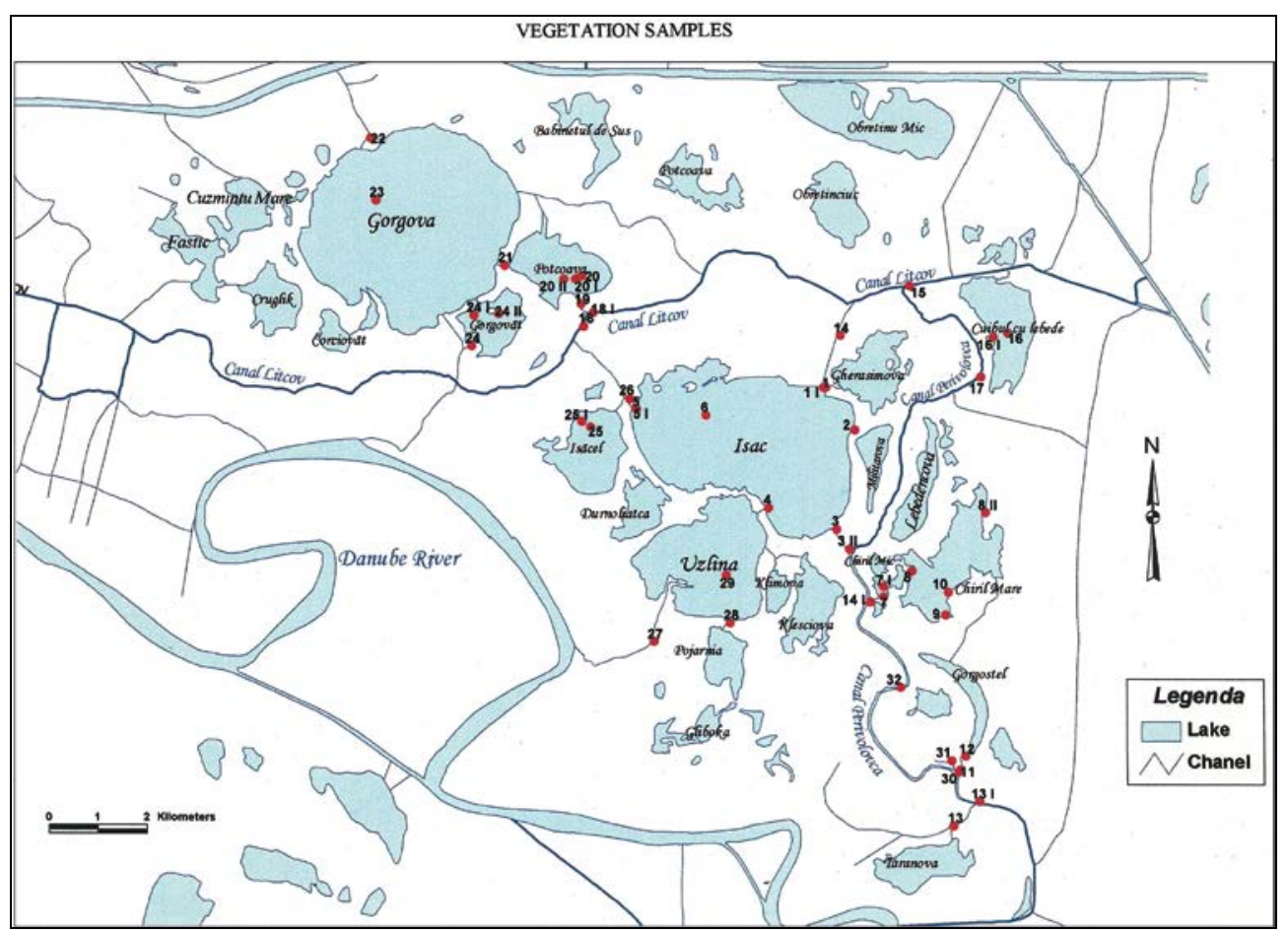

Figure 2: Map of the study area Gorgova-Isac-Uzlina with sampling points (source of map Danube Delta National Institute, Tulcea). 


\section{MATERIAL AND METHODS}

The paper presents a synthesis of water macrophyte researches over more than two decades in the Danube Delta and are the result of sampling and monitoring in the area of restoration projects of former agricultural polders and other area studied in relation to the implementation of the Water Framework Directive and the Natura 2000 network. To have an overview of the aquatic macrophytes known from the Danube Delta (Ciocârlan, 1994, 2009; Doroftei and Covaliov, 2003), data from smaller publication and our own field researches of all known species are listed (Tab. 1) showing for each species the life form, indicator values for light (L), temperature (T), wetness/humidity (U), indicator value for the preference of plants to chemical reaction of water and soil I, nitrogen (N) according to Ellenberg et al. (2002) as this scale is widely used in Europe. In some cases the value is re-adapted to the conditions of South-Eastern Romania (Sârbu et al., 2013) and verified according to Sanda et al. (1983). In the species list are given categories of threat according to the Red List of species of the Danube Delta (Fundația Aves, 2000; Dihoru and Negrean, 2009) and the occurrence in slow running (slr) and standing waters (st).

In the list of species, beside the aquatic life forms are included from the hydro-helophytes only those species that have aquatic forms, such as Polygonum amphibium, Sagittaria sagittifolia and Sparganium emersum, species with the indicator value for wetness 10 (hydro-helophytes). The indicator value 10 includes also aquatic species which support longer time without water or with changing water levels. The indicator values 11 (hydrophytes) includes species with roots in the water, with leaves above the water surface, floating and emerging over or floating on the water surface. The value 12 includes aquatic plants under the water surface, permanently or mostly covered by water.

From the large number of samples (125) taken by the method of Braun-Blanquet (1964) with the seven degree abundance-dominance scale only synthetic data are given including the frequency values (I-V) of each species of the community. A network of sampling points is represented with points in different type of water bodies like channels, canals and different type of lakes connected to the main branches, to secondary branches, canals and more isolated lakes. At each indicated point (Fig. 2) transparency, depth, temperature, ph and conductivity have been measured. The scientific names of the associations follow Sanda et al. (2008).

\section{RESULTS AND DISCUSSION}

The list of the macrophytic flora of the Danube Delta comprises 88 species (Tab. 1), including 11 stonewort (Characeae) species. Considering their indicator value for light, most species are in the categories 5-7, i.e. species in half-shadow to half-light conditions. The temperature requirements are expressed with values mostly between five moderate temperatures to indicators for temperature characteristic for the planar level and with some Mediterranean influences (Oberdorfer, 2001; Ellenberg et al., 2002). Concerning the $\mathrm{pH}$ values I, the species are mostly indicators for moderate to low acidity (indicator values five, six) and species as indicators for low alkaline to alkaline conditions (value seven). 
Table 1: List of aquatic macrophytes of the Danube Delta; indicator values for: $\mathrm{L}=$ light, $\mathrm{T}=$ temperature, $\mathrm{U}=$ umidity (Ellenberg et al., 2002) $\mathrm{F}=$ umidity/Feuchtigkeit, $\mathrm{R}=$ $\mathrm{pH} /$ soil reaction, $\mathrm{N}=$ nitrogen/nutrients, $\mathrm{ThrC}=$ threatening categories; fizical state: $\mathrm{r}=$ running water, slr = slowly running water, $\mathrm{st}=$ standing water.

\begin{tabular}{|c|c|c|c|c|c|c|c|c|c|}
\hline & Indicator value & $\mid$ & $H$ & כ & $\simeq$ & z & 导 & $=$ & $\ddot{\omega}$ \\
\hline Lifef. & Species & & & & & & & & \\
\hline Hd & Aldrovanda vesiculosa $\mathrm{L}$. & 5 & 8 & 12 & 7 & 4 & CR & - & st \\
\hline $\mathrm{HH}$ & Alisma gramineum Lej. & 7 & 7 & 11 & 7 & 4 & - & slr & st \\
\hline $\mathrm{HH}$ & Alisma lanceolatum With. & 7 & 7 & 10 & 7 & 5 & $\mathrm{R}$ & - & st \\
\hline $\mathrm{HH}$ & Alisma plantago-aquatica L. & 7 & 5 & 10 & $\mathrm{x}$ & 8 & - & slr & st \\
\hline $\mathrm{Hd}, \mathrm{T}$ & Azolla filiculoides Lam. & 6 & 8 & 11 & $\mathrm{x}$ & 8 & - & slr & st \\
\hline $\mathrm{HH}$ & Berula erecta (Huds.) Coville. & 8 & 6 & 10 & 8 & 6 & - & r slr & st \\
\hline G-HH & Butomus umbellatus L. & 6 & 6 & $10 \sim$ & $\mathrm{x}$ & 7 & - & slr & st \\
\hline $\mathrm{HH}$ & Caldesia parnassifolia (Bassi) Parl. & 7 & 7 & 10 & 8 & 7 & $\mathrm{EX}$ & - & st \\
\hline Hd & Callitriche palustris L. & 6 & $\mathrm{x}$ & 11 & 5 & 4 & - & - & st \\
\hline Hd & Ceratophyllum demersum L. & 6 & 7 & $12 \sim$ & 8 & 8 & - & $\operatorname{slr}$ & st \\
\hline $\mathrm{Hd}$ & Ceratophyllum submersum L. & 5 & 8 & 12 & 8 & 7 & $\mathrm{R}$ & - & st \\
\hline $\mathrm{Hd}$ & Elodea $\square$ btuse $\square$ sis Rich. In Michx & 7 & 6 & 12 & 7 & 7 & - & slr & st \\
\hline Hd & Elodea nuttallii (Planchon) H. St. John & 7 & 6 & 12 & ? & 7 & - & - & st \\
\hline $\mathrm{HH}$ & Glyceria maxima (Hartm.) Holmbg. & 9 & 5 & $10 \sim$ & 8 & 9 & - & slr & st \\
\hline $\mathrm{Hd}$ & Groenlandia densa (L.) Fourr. & 8 & 6 & 12 & 8 & 5 & VU, R & slr & st \\
\hline $\mathrm{Hd}$ & Hippuris vulgaris L. & 7 & 5 & 10 & 8 & 5 & VU & slr & st \\
\hline $\mathrm{Hd}$ & Hottonia palustris L. & 7 & 6 & 12 & 5 & 4 & VU, R & slr & st \\
\hline Hd & Hydrocharis morsus-ranae L. & 7 & 6 & 11 & 7 & 6 & - & slr & st \\
\hline Hd & Lemna gibba L. & 8 & 6 & 11 & 8 & 8 & - & - & st \\
\hline $\mathrm{Hd}$ & Lemna minor L. & 7 & 5 & 11 & $\mathrm{x}$ & 6 & 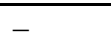 & - & st \\
\hline $\mathrm{Hd}$ & Lemna trisulca L. & 7 & 6 & 12 & 5 & 5 & - & - & st \\
\hline $\mathrm{Hd}$ & Marsilea quadrifolia L. & 7 & 9 & 10 & 7 & 6 & CR & - & st \\
\hline $\mathrm{Hd}$ & Myriophyllum spicatum L. & 5 & 6 & 12 & 9 & 7 & $\begin{array}{c}- \\
-\end{array}$ & $\operatorname{slr}$ & st \\
\hline $\mathrm{Hd}$ & Myriophyllum verticillatum L. & 5 & 6 & 12 & 7 & 8 & - & slr & st \\
\hline $\mathrm{Hd}$ & Najas marina L. & 5 & 6 & 12 & 9 & 6 & - & - & st \\
\hline $\mathrm{Hd}$ & Najas minor All. & 6 & 7 & 12 & 8 & $4 ?$ & - & - & st \\
\hline $\mathrm{Hd}$ & Nasturtium officinale R. Br. & 7 & $\mathrm{x}$ & 10 & 7 & 7 & - & r slr & - \\
\hline Hd & Nuphar lutea (L.) Sibth. Et Sm. & 8 & 6 & 11 & 7 & 6 & - & slr & st \\
\hline Hd & Nymphaea alba L. & 8 & 6 & 11 & 7 & 5 & - & - & st \\
\hline $\mathrm{Hd}$ & Nymphaea candida C. Presl. & 8 & 6 & 11 & 4 & 4 & $\mathrm{R}$ & - & st \\
\hline $\mathrm{Hd}$ & Nymphoides peltata (Gmel. S. G.) & 8 & 7 & 11 & 8 & 7 & - & slr & st \\
\hline $\mathrm{HH}$ & Oenanthe aquatica (L.) Poir. & 7 & 6 & 10 & 7 & 6 & - & slr & st \\
\hline $\mathrm{Hd}, \mathrm{G}$ & Polygonum amphibium L. & 7 & 6 & 11 & 6 & 4 & - & - & st \\
\hline Hd & Potamogeton acutifolius Link & 7 & 6 & 12 & 5 & 6 & - & slr & st \\
\hline $\mathrm{Hd}$ & Potamogeton berchtoldii Fieber & 6 & 6 & 12 & 7 & 5 & $\overline{\mathrm{R}}$ & - & st \\
\hline $\mathrm{Hd}$ & Potamogeton compressus L. & 6 & 5 & 12 & 8 & 4 & $\mathrm{R}$ & slr & st \\
\hline Hd & Potamogeton crispus L. & 6 & 5 & 12 & 7 & 5 & $\overline{-}$ & $\operatorname{slr}$ & st \\
\hline $\mathrm{Hd}$ & Potamogeton gramineus L. & 8 & 4 & 12 & 5 & 3 & - & - & st \\
\hline
\end{tabular}


Table 1 (continued): List of aquatic macrophytes of the Danube Delta; indicator values for: $\mathrm{L}=$ light, $\mathrm{T}=$ temperature, $\mathrm{U}=$ umidity (Ellenberg et al., 2002) $\mathrm{F}=$ umidity/Feuchtigkeit, $\mathrm{R}=\mathrm{pH} /$ soil reaction, $\mathrm{N}=$ nitrogen/nutrients, $\mathrm{ThrC}=$ threatening categories; fizical state: $\mathrm{r}=$ running water, slr $=$ slowly running water, st $=$ standing water.

\begin{tabular}{|c|c|c|c|c|c|c|c|c|c|}
\hline $\mathrm{Hd}$ & Potamogeton lucens L. & 6 & 6 & 12 & 6 & 7 & - & - & st \\
\hline $\mathrm{Hd}$ & Potamogeton natans L. & 6 & 5 & 11 & 7 & 5 & - & - & st \\
\hline Hd & Potamogeton nodosus Poiret & 6 & 6 & 12 & 8 & 5 & - & $\operatorname{slr}$ & st \\
\hline Hd & Potamogeton pectinatus L. & 6 & $\mathrm{x}$ & 12 & 8 & 8 & - & slr & st \\
\hline $\mathrm{Hd}$ & Potamogeton perfoliatus L. & 6 & $\mathrm{x}$ & 12 & 7 & 6 & - & slr & st \\
\hline Hd & Potamogeton pusillus L. & 6 & 5 & 12 & 6 & $\mathrm{x}$ & $\mathrm{R}$ & $\operatorname{slr}$ & st \\
\hline $\mathrm{Hd}$ & Potamogeton trichoides Cham. And Schlec. & 8 & 6 & 11 & 5 & 4 & $\mathrm{R}$ & slr & st \\
\hline Hd & Ranunculus aquatilis L. & 7 & 5 & 11 & 6 & 6 & - & $\operatorname{slr}$ & st \\
\hline $\mathrm{Hd}$ & Ranunculus baudotii Godr. & 8 & 6 & 10 & 9 & 7 & - & - & st \\
\hline Hd & Ranunculus circinatus Sibth. & 6 & 6 & 12 & 7 & 8 & $\mathrm{R}$ & - & st \\
\hline Hd & Ranunculus fluitans Lam. & 8 & 6 & 12 & $\mathrm{x}$ & 8 & - & $\mathrm{r}$ & - \\
\hline $\mathrm{Hd}$ & Ranunculus peltatus Schrank & 8 & 5 & 12 & $\mathrm{x}$ & 5 & - & - & st \\
\hline Hd & Ranunculus penicillatus (Dumort) Bab. & 8 & 6 & 11 & 7 & $\mathrm{x}$ & - & - & st \\
\hline Hd & Ranunculus rionii Lagger & 8 & 6 & 12 & $\mathrm{x}$ & 5 & - & - & st \\
\hline $\mathrm{Hd}$ & Ranunculus trichophyllus Chaix. & 7 & $\mathrm{x}$ & 12 & 5 & 7 & - & $\mathrm{r}$ & - \\
\hline $\mathrm{HH}$ & Rorippa amphibia (L.) Bess. & 7 & 6 & 10 & 7 & 8 & - & $\operatorname{slr}$ & st \\
\hline $\mathrm{Hd}$ & Ruppia maritima L. & $\mathrm{X}$ & 6 & 10 & 7 & ? & VU, R & - & st \\
\hline $\mathrm{Hd}$ & Ruppia cirrhosa (Petagna) Grande & $\mathrm{x}$ & 6 & 10 & 7 & - & VU & - & st \\
\hline $\mathrm{HH}$ & Sagittaria latifolia Willd & 7 & 6 & 10 & - & - & $\overline{-}$ & - & st \\
\hline $\mathrm{HH}$ & Sagittaria sagittifolia L. & 7 & 6 & 10 & 7 & 6 & - & slr & st \\
\hline $\mathrm{HH}$ & Sagittaria trifolia L. & 7 & 6 & 10 & 7 & - & VU & $\operatorname{slr}$ & st \\
\hline $\mathrm{Hd}$ & Salvinia natans (L.) All. & 7 & 8 & 11 & 7 & 7 & $\mathrm{BrI}$ & - & st \\
\hline Hd & Sparganium emersum Rehm. & 7 & 6 & 10 & 6 & 7 & $\overline{-}$ & $\operatorname{slr}$ & st \\
\hline Hd & Spirodela polyrhiza (L.) Schleiden & 7 & 6 & 11 & 6 & 6 & - & - & st \\
\hline $\mathrm{HH}$ & Stratiotes aloides L. & 7 & 6 & 12 & 8 & 6 & - & slr & st \\
\hline Hd & Trapa natans L. & 8 & 7 & 11 & 6 & 8 & nt/Br. I & - & st \\
\hline $\mathrm{Hd}$ & Utricularia australis R. Br. & 9 & 6 & 12 & 5 & $3 ?$ & $\mathrm{R}$ & - & st \\
\hline $\mathrm{Hd}$ & Utricularia bremii Heer & 8 & 7 & 12 & 3 & $2 ?$ & - & - & st \\
\hline $\mathrm{Hd}$ & Utricularia minor L. & 8 & 6 & 12 & 6 & $2 ?$ & EX & - & st \\
\hline $\mathrm{Hd}$ & Utricularia vulgaris L. & 7 & 6 & 12 & 5 & 4 & - & - & st \\
\hline Hd & Vallisneria spiralis L. & 7 & 8 & 12 & 7 & 7 & - & $\operatorname{slr}$ & st \\
\hline Hd-HH & Veronica anagallis-aquatica L. & 7 & 6 & $9=$ & $\mathrm{x}$ & 6 & - & slr & - \\
\hline $\begin{array}{l}\mathrm{Hd}-\mathrm{HH} \\
\end{array}$ & Veronica beccabunga L. & 7 & $\mathrm{x}$ & 10 & 7 & 6 & - & $\operatorname{slr}$ & - \\
\hline Hd-HH & Veronica scutellata L. & 8 & 5 & $9=$ & 3 & 3 & - & - & st \\
\hline $\mathrm{Hd}$ & Wolffia $\square$ btuse (L.) Horkel ex Wimm. & 7 & 6 & 11 & 7 & $6 ?$ & - & - & st \\
\hline $\mathrm{Hd}$ & Zannichellia palustris L. & 6 & 7 & 12 & 7 & 6 & $\mathrm{R}$ & - & st \\
\hline $\mathrm{Hd}$ & Z.pal.pedicellata (Wlbg and Rosén) Arcang & 6 & 7 & 12 & 7 & 6 & $\mathrm{R}$ & - & st \\
\hline $\mathrm{Hd}$ & Zostera noltii Hornem. & 7 & 6 & 12 & 7 & 6 & VU, R & & st \\
\hline $\mathrm{Hd}$ & Zostera marina L. & $\mathrm{X}$ & 6 & 12 & 7 & 6 & VU & & st \\
\hline $\mathrm{Hd}$ & Chara aspera Deth. Ex Willd. & - & - & - & - & - & - & - & st \\
\hline $\mathrm{Hd}$ & Chara contraria Braun A. & - & - & - & - & - & - & - & st \\
\hline $\mathrm{Hd}$ & Chara crassicaulis Schleicher & - & - & - & - & - & - & - & st \\
\hline Hd & Chara globularis Thuill. & - & - & - & - & - & 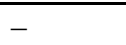 & - & st \\
\hline Hd & Chara gymnophylla Braun A. & - & - & - & - & - & $\begin{array}{l}- \\
\end{array}$ & - & st \\
\hline
\end{tabular}


Table 1 (continued): List of aquatic macrophytes of the Danube Delta; indicator values for: $\mathrm{L}=$ light, $\mathrm{T}=$ temperature, $\mathrm{U}=$ umidity (Ellenberg et al., 2002) $\mathrm{F}=$ umidity/Feuchtigkeit, $\mathrm{R}=\mathrm{pH} /$ soil reaction, $\mathrm{N}=$ nitrogen/nutrients, $\mathrm{ThrC}=$ threatening categories; fizical state: $\mathrm{r}=$ running water, slr = slowly running water, $\mathrm{st}=$ standing water.

\begin{tabular}{|c|l|c|c|c|c|c|c|c|c|}
\hline $\mathrm{Hd}$ & Chara hispida Linné & - & - & - & - & - & - & - & st \\
\hline $\mathrm{Hd}$ & Chara tomentosa Linné & - & - & - & - & - & $\mathrm{EX}$ & - & st \\
\hline $\mathrm{Hd}$ & Chara vulgaris Linné & - & - & - & - & - & - & - & st \\
\hline $\mathrm{Hd}$ & Nitella gracilis (Smith) Agardh & - & - & - & - & - & EX? & - & st \\
\hline $\mathrm{Hd}$ & Nitella syncarpa (Thuill.) Chev. & - & - & - & - & - & EX? & - & st \\
\hline $\mathrm{Hd}$ & Nitelopsis obtusa (Desv. In Lois. - Desl.) J. Grov. & - & - & - & - & - & - & - & st \\
\hline
\end{tabular}

The analysis of indicator values for Nitrogen of the macrophytes according to Ellenberg et al. (2002) shows a predominance of species with values of four to eight, the majority of species are represented in the value classes of six and seven (Fig. 2). This high presence of nitrophilous species indicates the general eutrophic character of the system. This can be followed by studies of the vegetation along ecological gradients from the main branches to the larger secondary channels, the smaller ones and to the lakes.

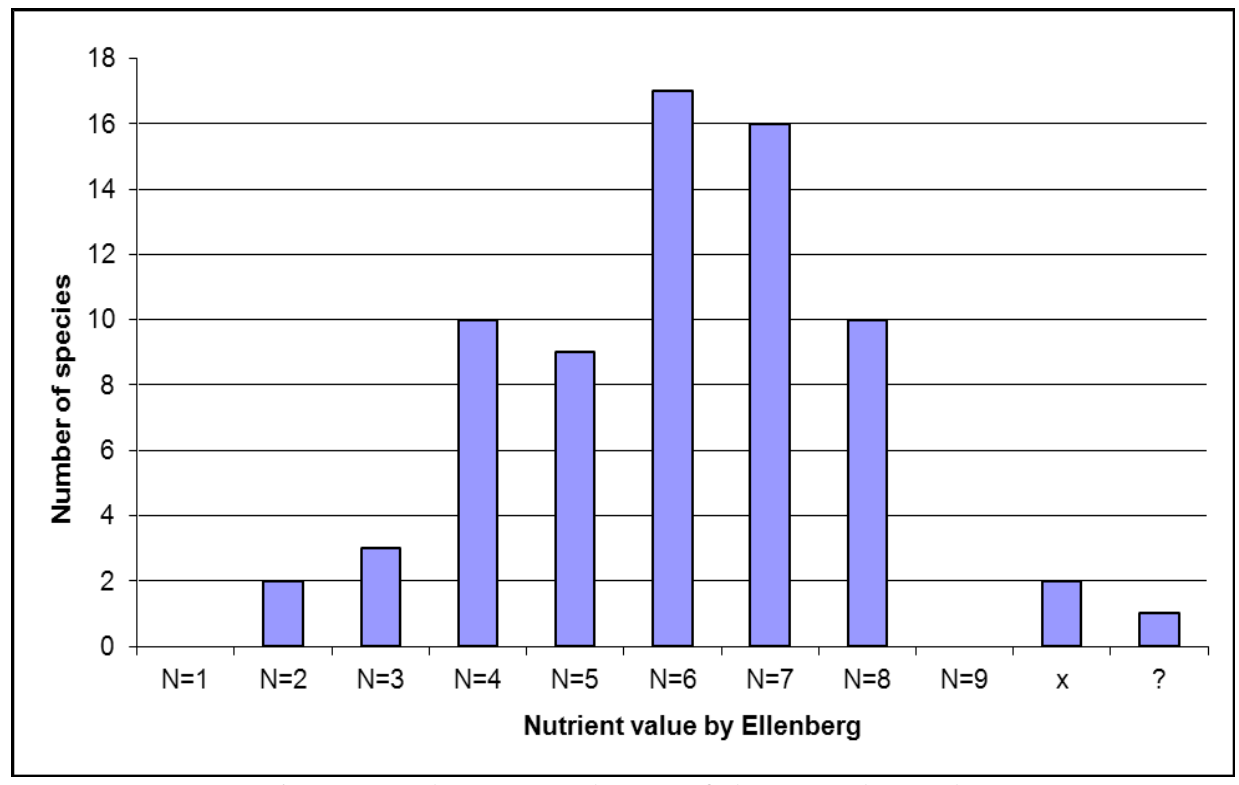

Figure 3: The macrophytes of the Danube Delta grouped according to categories of nutrient values (Nitrogen).

Concerning the category of threat, the list of aquatic macrophytes includes some Rare, Vulnerable and Critically Endangered species and also species considered as Extinct. In the list is included also water chestnut (Trapa natans) and floating water-moss (Salvinia natans), species which in the Danube Delta occur frequently and at high abundance. These species are endangered and rare in Middle and Western Europe, being thermophilous species on the border of their distribution boundary. 
A remarkable regressive tendency can be observed for stonewort species, some of which are endangered by extinction or are considered as extinct. The following species have been mentioned from the Danube Delta area and are included in the above-mentioned list.

Chara aspera Detharding ex Willdenow 1809 occurs in lakes with clear and calcium carbonate-rich water in Central and Western Europe, but also in Southern Europe to a depth of $1.5 \mathrm{~m}$. The species builds communities which in deeper waters are followed frequently by those of Chara contraria, which in its turn is replaced at increasing depth by communities of Nitelopsis $\square$ btuse (Krause, 1997). In the Danube Delta these species have been found in the Polder Popina area in the north-eastern part of the Danube Delta, building together with Chara vulgaris communities with a high degree of cover. (observation and monitoring Schneider 2000 and 2001).

Chara contraria Braun A. ex Kütting 1845 is characteristic of meso-saprobic clear lakes and occurs in small temporary lakes and pools as was reported on the Babina restored area (western part) and in the area of Popina in water of slight salinity (Schneider et al., 2008).

Chara gymnophylla Braun A. 1835, a circum-Mediterranean and South-Eastern species builds monospecific communities in small lakes of dry regions. In the Danube Delta area stands with this species have been registered during studies in the restoration area of island-polder Cernovca (Schneider, 1998 - personal data). It is rare all over its distribution area (Krause, 1997).

Chara globularis Thuill. 1799 is a more widespread species in calcium carbonate-rich waters reaching high dominance as was reported in the Cernovca restoration area lakes and the lakes Chiril Mare and Clesciova. Its fast growth allows the species to spread in a short time over a large area (Krause, 1997).

Chara hispida L. 1753 until the present was not mentioned for the Danube Delta. We found the species in 2003 in the Nebunu Lake in the northern end of the Letea Dune area, nearby the village of Periprava. It is characteristic for calcium carbonate-rich oligo-saprobic waters on mineral soils with high organic matter content. As well its growth is stimulated through the influx of groundwater supply. The species is known for its high requirements for clean waters (Krause, 1997), as they are given in function of the water level of the Danube in strong relation with the ground water table and the filtering capacity of the dune area.

As one of the most frequent species recorded was Chara vulgaris L. 1753, a widely distributed species. It occurs in lakes with meso-saprobic water quality. This species with a high capacity for fast growth can occupy a large area in a short time. As well Chara vulgaris is more resistant to eutrophication as other Characeae species (Krause, 1997). In the Danube Delta restoration area we reported the species in the area of Popina polder and the Cernovca area. As well, another Characeae species Chara crassicaulis Schleicher 1821 has been found in small lakes and also temporary pools in the re-flooded Cernovca polder area. The species with a distribution in Central and South-Eastern Europe is characteristic for waters with direct supply from groundwater.

The stonewort species Chara tomentosa L. 1753 has been mentioned as Charetum tomentosae (Sauer 1937) Corillion 1957 from the Danube Delta in the area of Şontea-Sireasa and the lake area of Roşu-Roşuleţ (Godeanu, 1976). Although this species is given from the Danube Delta, it is not mentioned by Krause (1997) from Romania. Due to increasing eutrophication, the species was not identified in recent decades.

As a characteristic species of lakes with clear and deeper waters for many lakes of the fluvial part of the Danube Delta should be mentioned Nitellopsis $\square$ btuse (Desvaux in Loisleur-Deslangchamps) Groves J. 1919. It occurs in deeper lakes (5-10 m) in exclusive stands. 


\section{Aquatic plant communities}

Due to the above-mentioned high diversity of water body types in the Danube Delta, the macrophyte vegetation presents in its distribution a distinct mosaic of interlocking communities. This mosaic is exemplified in the lakes area of Gorgova-Isac-Uzlina between the main branches Sulina and Sfântul Gheorghe with secondary water courses such as Perivolovca (more natural) and Litcov (more artificial), third and fourth category of waters consisting of smaller and narrow channels between the larger channels and lakes. These last are represented by large lakes such as Gorgova, Isac and Uzlina, as well as numerous smaller lakes connected to the larger ones by small channels (gârla), but also some small lakes more isolated in the reeds.

Analysing the differences between running and standing waters, there is a clear delineation of occurrence for the pondweed species Potamogeton nodosus, which occurs at high abundance and constancy only in running waters (Schneider, 2009) such as for the studied area the Litcov Canal, Uzlina Canal and some smaller channels such are the Isac I and II. Near Potamogeton nodosus are some accompanying species such as Potamogeton perfoliatus, Trapa natans, Nuphar lutea, Ceratophyllum demersum and Potamogeton pectinatus, which beside their occurrence in standing water are present also in slowly running waters. The identifies, together with Potamogeton nodosus, transition stages from running to standing waters (Tab. 2). Potamogton nodosus (Fig. 4) occurs also in the main branches, as it has been observed on the Danube's mile 2 near to Sulina in 2011.

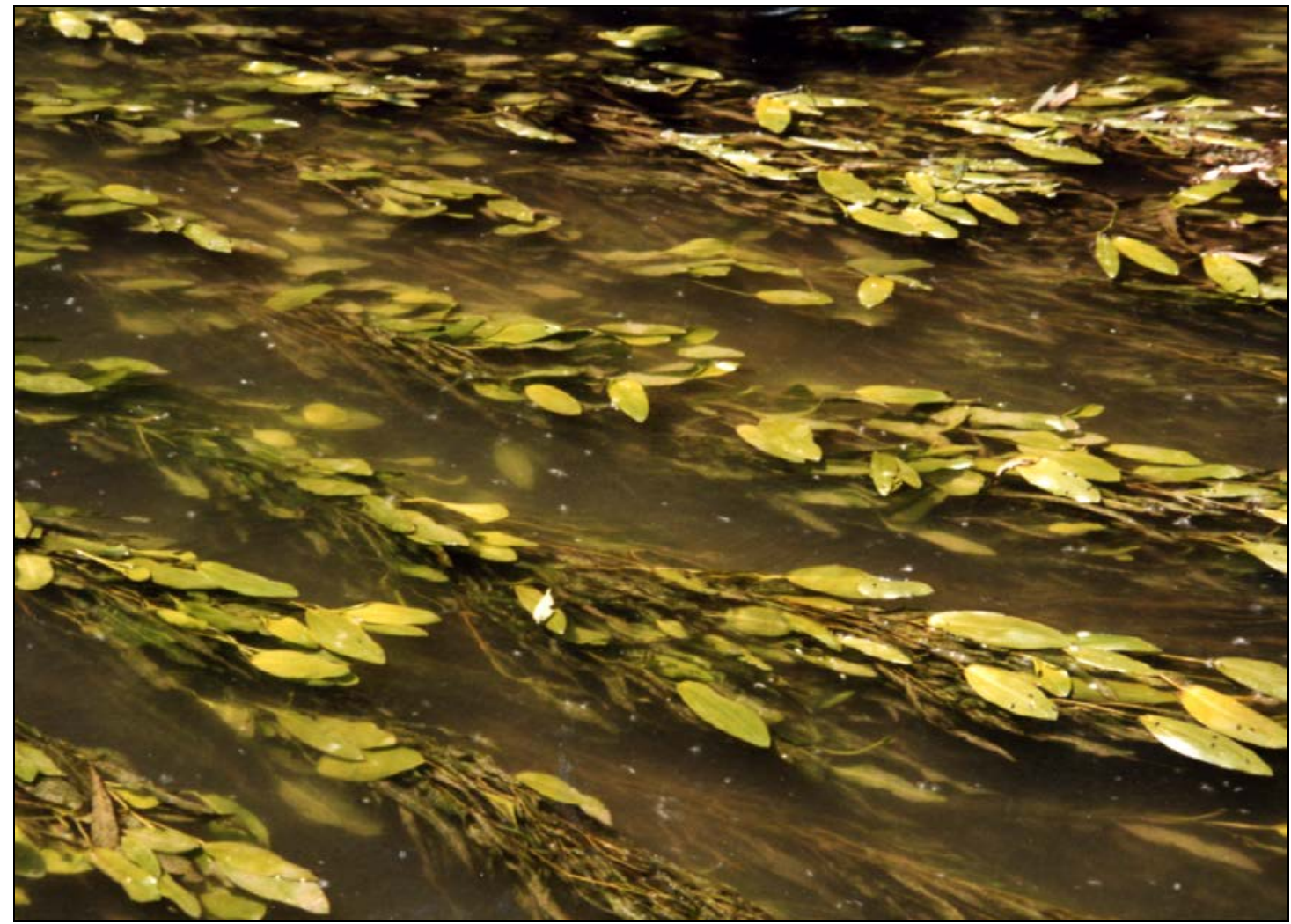

Figure 4: Potamogeton nodosus, characteristic species for running waters. 
Another species occurring in standing shallow water but also in running waters without slope is Nymphoides peltata. The species has been remarked in the Litcov Channel constituting large patches on the edge of the water together with Butomus umbellatus, a good indicator for shallow waters in the course of silting up. Nymphoides peltata has been observed also in the border area of the main Chilia Branch, downstream from Periprava.

A species that has spread more recently is Elodea nutallii, replacing more and more Elodea $\square$ btuse $\square$ sis. From its first mention in the Danube Delta (Ciocârlan et al., 1998) the species had a high dispersal, occupying at present a larger area and stable communities.

Apart from Potamogeton nodosus all the other species can occur and identify phytocoenoses also in the standing waters and are present in the lakes following ecological gradients. The repartition is different in function of the water current and nutrient content. The communities identified by Trapa natans occur in places near to the connectivity channels from where a quantity of nutrients transported by running waters enters into the lake as is visible in the Uzlina Lake. In sediment-rich lakes Trapa natans can act with its root system as a trap for fine sediments, as has been observed in the case of Rotund (formerly Cruglic) lake north of the Sulina Branch. It plays a similar role in the Uzlina area.

In the large lakes such as Isac and Gorgova large parts are settled by Potamogeton pectinatus with Potamogeton trichoides, also in some places the small pondweed Potamogeton bertholdii which requires clear and more mesotrophic habitats.

In general can be stated gradients between lakes and channels, gradients in the lakes, gradients between the different lakes, gradients in the channels from the river bank to the mid of the water course, in dependence of the river bank structure, the depth of the water and the flow velocity.

In smaller channels crossing the reeds such as the Lopadna and Eracle Channels, the macrophyte communities are situated along the reeds, forming smaller or larger belts. In transects the following structures can be observed:

Lopadna:

Phragmites australis reed - Trapa natans stands - open water in mid-channel - Trapa natans - Phragmites reed;

Eracle:

Phragmites reed - Trapa natans stands - open water - Trapa stands - Nymphaea alba - Phragmites reed;

Phragmites reed - Trapa natans stands - open water - Trapa natans stands - Nuphar luteum stands - Nymphaea alba stands - Phragmites reed;

Phragmites reed - Nuphar luteum stands - Trapa natans stands - open water - Trapa natans stands - Phragmites reed;

Crossing point of Lopadna and Eracle:

Phragmites reed - Stratiotes aloides stands - Trapa natans stands - Salvinia natans cover - open water surface in the mid - Salvinia natans cover - Trapa natans stands, Nymphaea alba stands - Stratiotes aloides stands Phragmites reeds;

This succession is characteristic for the channels in the fluvial part of the delta and indicates - in the places with presence of Stratiotes aloides - active evolution of "plav" or floating reed formations, Stratiotes aloides building the support for the reeds, which fall down and on the nodes of the lying stems grow new small stems and leaves of Phragmites, covering in time the Stratiotes belt. 
Table 2: Synthetic table of macrophyte communities based on frequency classes; $\mathrm{A}=$ association, the other are accompanying species. Colum 1: Potamogetonetum nodosi with samples from Litcov Canal, Uzlina Canal, mouth of Isac Canal II into Isac Lake, (habitat type 3260); Column 2: Potamogetonetum perfoliati subass. With Potamogeton nodosus, high constancy, but lower abundance-dominance as the name giving species (Litcov, Uzlina and Caraorman Canal); Column 3: Trapetum natantis with samples (from the Uzlina, Iacub, Gorgova, Gorgoştel lakes); Column 4: Trapetum natantis facies with Stratiotes aloides (gârla between Gorgoștel Lake and Perivolovca Canal); Column 5: Stratiotetum aloidis, gârla Gorgoștel, fac. With Hydrocharis morsus ranae from Taranova Lake; Column 6: Nymphaeetum albae (with high frequency of Trapa natans but low abundance-dominance) from the Cuibul cu Lebăda Lake, Chiril Mic, Clesciova; Column 7: Nupharetum luteae (Perivolovca, Chiril Mare, Gorgoștel with samples from the whole lake area); Column 8: Ceratophylletum demersi with Elodea nutallii and Myriophyllum spicatum (Cuibul cu Lebăda Lake); Column 9: Potamogetonetum pectinati from Isac Lake, Gorgova; Column 10: Nitellopsidetum obtusae (Potcoava Lake, Chiril Mare) the species occurs with high frequency also in the association Ceratophylletum demersi, but with low abundance; Column 11: Nymphoidetum peltatae (Litcov Canal).

\begin{tabular}{|l|l|c|c|c|c|c|c|c|c|c|c|c|}
\hline & $\begin{array}{l}\text { Serial number } \\
\text { of column }\end{array}$ & 1 & 2 & 3 & 4 & 5 & 6 & 7 & 8 & 9 & 10 & 11 \\
\hline No. of samples & 25 & 10 & 11 & 5 & 10 & 5 & 25 & 6 & 21 & 5 & 5 \\
\hline A & $\begin{array}{l}\text { Potamogeton } \\
\text { nodosus }\end{array}$ & V & V & - & - & - & - & - & - & I & - & - \\
\hline A & $\begin{array}{l}\text { Potamogeton } \\
\text { perfoliatus }\end{array}$ & III & V & - & - & - & - & - & - & - & - & - \\
\hline A & $\begin{array}{l}\text { Trapa } \\
\text { natans }\end{array}$ & III & III & V & V & I & I & - & I & II & - & - \\
\hline A & $\begin{array}{l}\text { Stratiotes } \\
\text { aloides }\end{array}$ & - & - & I & II & V & IV & - & - & I & - & - \\
\hline A & $\begin{array}{l}\text { Hydrocharis } \\
\text { morsus-ranae }\end{array}$ & - & - & I & - & V & I & - & - & I & - & - \\
\hline A & $\begin{array}{l}\text { Nymphaea } \\
\text { alba }\end{array}$ & - & - & - & - & I & V & II & - & - & - & - \\
\hline A & $\begin{array}{l}\text { Nuphar } \\
\text { luteum }\end{array}$ & I & - & II & II & - & II & V & - & I & - & - \\
\hline A & $\begin{array}{l}\text { Ceratophyllum } \\
\text { demersum }\end{array}$ & II & III & IV & V & III & III & - & V & III & II & - \\
\hline A & $\begin{array}{l}\text { Potamogeton } \\
\text { pectinatus }\end{array}$ & III & III & I & II & - & - & I & II & V & III & - \\
\hline A & $\begin{array}{l}\text { Nymphoides } \\
\text { peltata }\end{array}$ & I & - & - & - & - & - & - & - & - & - & V \\
\hline & $\begin{array}{l}\text { Potamogeton } \\
\text { crispus }\end{array}$ & I & I & I & III & - & - & I & - & III & I & - \\
\hline $\begin{array}{l}\text { Myriophyllum } \\
\text { spicatum }\end{array}$ & - & - & - & - & I & - & - & III & I & - & - \\
\hline
\end{tabular}


Table 2 (continued): Synthetic table of macrophyte communities on the base of frequency classes.

\begin{tabular}{|c|c|c|c|c|c|c|c|c|c|c|c|c|}
\hline & \begin{tabular}{|l|}
$\begin{array}{l}\text { Serial number } \\
\text { of column }\end{array}$ \\
\end{tabular} & 1 & 2 & 3 & 4 & 5 & 6 & 7 & 8 & 9 & 10 & 11 \\
\hline & No. of samples & 25 & 10 & 11 & 5 & 10 & 5 & 25 & 6 & 21 & 5 & 5 \\
\hline & \begin{tabular}{|c|} 
Elodea \\
nutalii \\
\end{tabular} & I & - & II & - & - & II & II & III & I & III & - \\
\hline & \begin{tabular}{|l|} 
Potamogeton \\
trichoides \\
\end{tabular} & - & - & I & - & - & - & I & - & II & II & - \\
\hline & \begin{tabular}{|l|} 
Potamogeton \\
berchtoldii
\end{tabular} & - & - & - & - & - & - & I & - & II & II & - \\
\hline & $\begin{array}{l}\text { Potamogeton } \\
\text { lucens }\end{array}$ & - & I & - & - & - & - & I & - & - & - & - \\
\hline A & \begin{tabular}{|l|} 
Nitelopsis \\
obtusa
\end{tabular} & - & - & - & - & - & - & I & IV & I & V & - \\
\hline & \begin{tabular}{|l|} 
Chara \\
globularis
\end{tabular} & - & - & - & - & - & - & - & - & I & - & - \\
\hline & $\begin{array}{l}\text { Lemna } \\
\text { minor }\end{array}$ & I & - & I & III & II & I & - & II & I & - & - \\
\hline & \begin{tabular}{|l|} 
Lemna \\
trisulca \\
\end{tabular} & - & - & I & I & I & I & - & II & - & - & - \\
\hline & \begin{tabular}{|l|} 
Spirodela \\
polyrhiza
\end{tabular} & II & - & II & IV & III & II & I & - & II & - & - \\
\hline & $\begin{array}{l}\text { Salvinia } \\
\text { natans }\end{array}$ & I & - & II & II & IV & II & - & II & - & - & I \\
\hline & $\begin{array}{l}\text { Berula } \\
\text { erecta }\end{array}$ & - & - & - & - & I & - & - & - & - & - & - \\
\hline & \begin{tabular}{|l|} 
Phragmites \\
australis
\end{tabular} & I & - & I & I & I & - & I & - & - & - & - \\
\hline & $\begin{array}{l}\text { Sagittaria } \\
\text { sagittifolia }\end{array}$ & - & - & I & I & - & - & - & - & I & - & I \\
\hline & \begin{tabular}{|l|} 
Alisma \\
lanceolatum \\
\end{tabular} & - & I & - & - & - & - & - & - & - & - & - \\
\hline & \begin{tabular}{|l|} 
Vallisneria \\
spiralis
\end{tabular} & - & - & - & - & - & - & I & - & - & - & - \\
\hline & $\begin{array}{l}\text { Alisma planta- } \\
\text { go aquatica }\end{array}$ & - & - & - & - & - & - & I & - & - & - & - \\
\hline & \begin{tabular}{|l|} 
Thelypteris \\
palustris
\end{tabular} & - & - & - & - & - & - & - & I & - & - & - \\
\hline & $\begin{array}{l}\text { Polygonum } \\
\text { amphibium }\end{array}$ & - & - & - & - & - & - & - & - & I & - & - \\
\hline & $\begin{array}{l}\text { Ceratophyllum } \\
\text { submersum }\end{array}$ & - & - & - & - & - & - & - & - & I & - & - \\
\hline & \begin{tabular}{|l|} 
Butomus \\
umbellatus
\end{tabular} & - & - & - & - & - & - & - & - & - & - & II \\
\hline
\end{tabular}




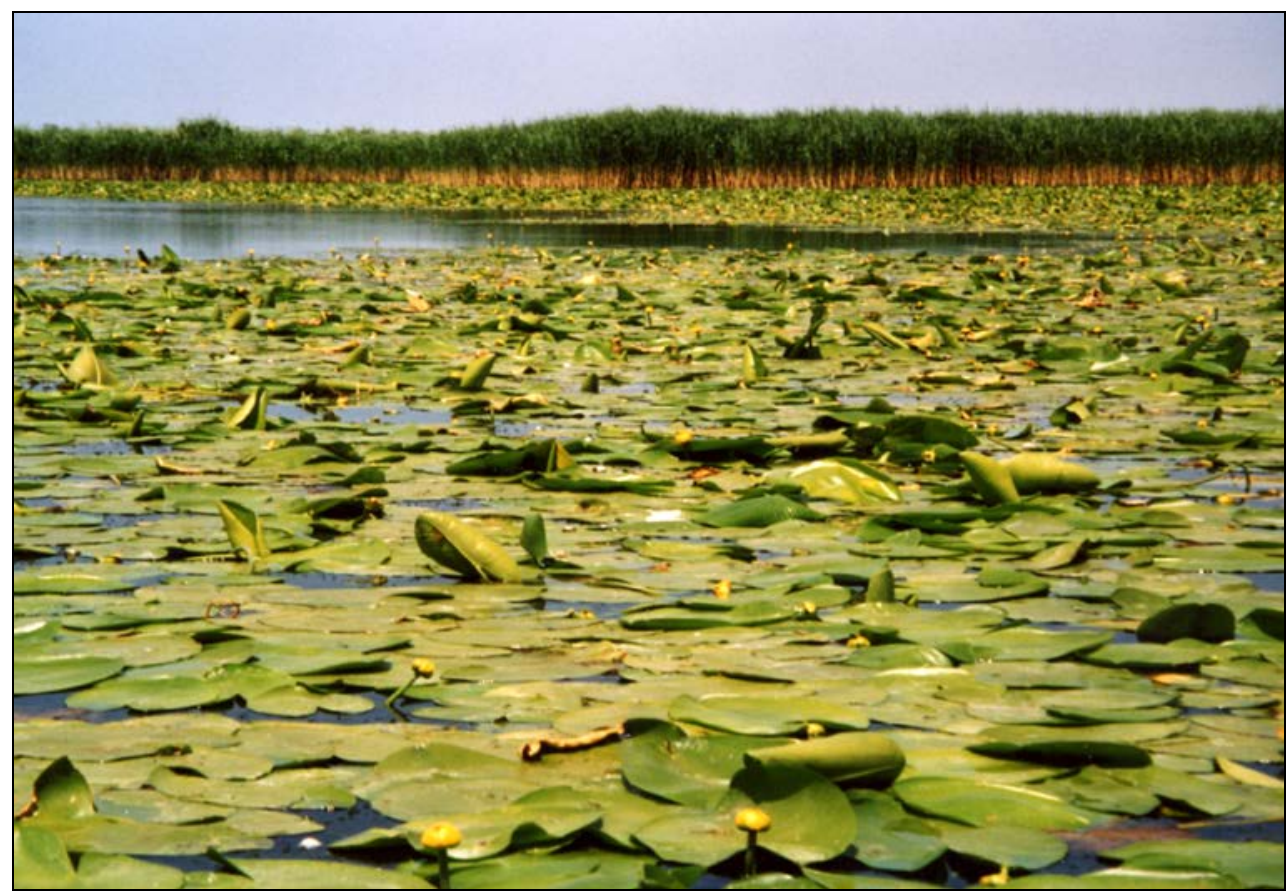

Figure 5: Nuphar lutea carpets in the lake "Cuibul cu Lebăda" in eutrophic conditions.

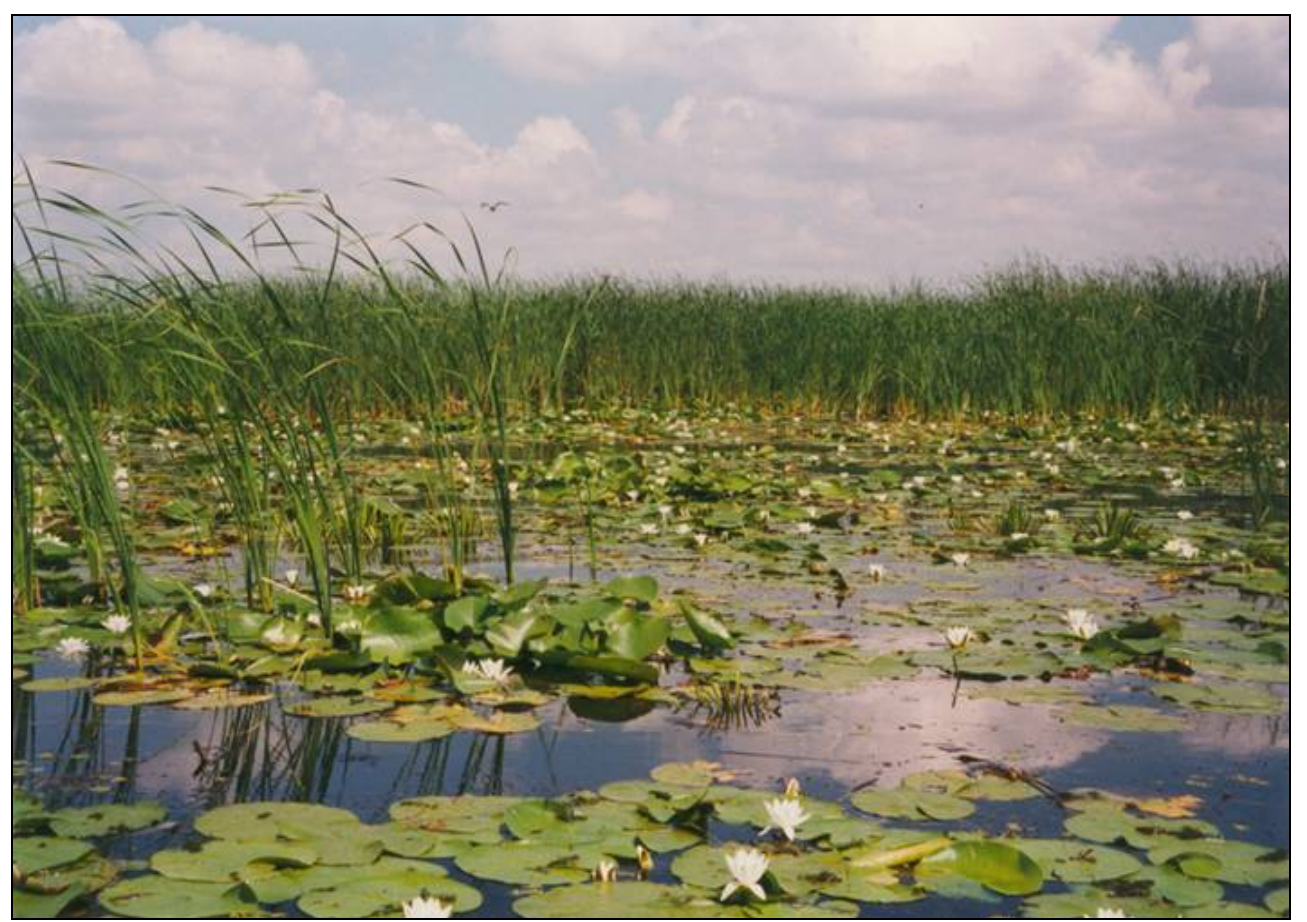

Figure 6: White water lily (Nymphaea alba) community with Nuphar in moderate eutrophic conditions. 
In smaller lakes with structured borders and connectivity to channels can be observed a repartition of communities or fragments of them in function of water current and border structure of the lake. For example in the "Cuibul cu lebăda" southern part there are concentrated communities of Nitellopsis $\square$ btuse and Elodea nutallii together with Potamogeton crispus and P. pectinatus. In the western part near to the bordering reed beds we found stands of white water lily (Nymphaea alba) and Stratiotes aloides, whereas more to the open part of the lake stands of Nuphar lutea prevail (Fig. 5). In channels have also been observed a belt of Nymphaea on the border of the reeds where the water enters cleaner and filtered through the reeds, in some cases interlocking with Stratiotes and followed by Nuphar luteum stands. In old channels of the "gârla" type the most dominant species is Stratioates aloides, in some cases accompanied by Hydrocharis morsus-ranae.

In most specific cases can be observed regressive tendencies for the species living in mesotrophic conditions and an increase of species with larger ecological amplitude such as Potamogeton pectinatus and Ceratophyllum demersum.

The majority of Characeae species are good indicators for water quality. They have been studied in the 1970s (Godeanu and Țeculescu, 1971) in the context of macrophyte communities of the Danube Delta. The association Charetum tomentosae (Sauer 1937) Corillion 1957 has been mentioned in the area of Şontea-Sireasa and the lake area of RoşuRoşuleţ (Godeanu and Ionescu-Ţeculescu, 1971; Godeanu, 1976). Although the species and its communities are described from the Danube Delta they are not mentioned by Krause (1997) from Romania. Due to increasing eutrophication, this species and its communities were not identified in the last decades.

The association Nitellopsidetum obtusae, almost characteristic for beta-meso-saprobic lakes (Krause, 1997), can support in the frame of larger limits eutrophication. During field research communities with Nitellopsis $\square$ btuse were reported in the Isac-Uzlina area in the lakes Taranova, Chiril Mare, Cuibul cu Lebăda, and Clesciova, but on a reduced scale and with visible regress. This is in strong relation to eutrophication; especially the content of phosphorus with values higher than $20 \mathrm{mg} / \mathrm{l}$ is a factor for decrease of Characeae populations, because the phosphorus content is favoring the development of plankton, which in turn promotes increasing plankton quantity, causing turbidity. As well the increasing phosphorus content promotes the development of macrophytes and an increased organic production. Also high nitrogen content promotes the macrophytes, but displaces the stoneworts (Krause, 1997).

According to the list of European Union habitats (EUR28, 2013) including the habitat type 3150 Natural eutrophic lakes with Magnoüotamion or Hydrocharitiontype vegetation, only the Potamogeton nodosus community is typical for running waters and has to be included in the habitat type 3260 Water courses of the plain to montane levels with the Ranunculion fluitantis and Callitricho-Batrachion vegetation, being a transition type to the macrophyte communities included in the habitat type of eutrophic lakes. 
Table 3: Plant communities of the study area according to Neagu-Godeanu (1973, 1975) and data from the last two decades (Schneider-Binder).

\begin{tabular}{|c|c|c|}
\hline & $\begin{array}{l}\text { Associations according to Neagu- } \\
\text { Godeanu } 1973 \text { and } 1975\end{array}$ & $\begin{array}{l}\text { Associations according to recent } \\
\text { data }\end{array}$ \\
\hline 1. & $\begin{array}{l}\text { Charetum tomentosae (Sauer } \\
\text { 1937), Corillion } 1957\end{array}$ & Not mentioned in the last time \\
\hline 2. & $\begin{array}{l}\text { Nitellopsidetum obtusae (Sauer } \\
\text { 1937) Dombska } 1961\end{array}$ & $\begin{array}{l}\text { Nitellopsidetum obtusae (Sauer } \\
\text { 1937) Dombska } 1961\end{array}$ \\
\hline 3. & $\begin{array}{l}\text { Ceratophylletum demersi Hild } \\
1956\end{array}$ & $\begin{array}{l}\text { Ceratophylletum demersi Hild } \\
1956\end{array}$ \\
\hline 4. & $\begin{array}{l}\text { Stratiotetum aloidis Nowinski } \\
1930\end{array}$ & $\begin{array}{l}\text { Stratiotetum, aloidis Nowinski } \\
1930 \text { ( = Hydrochari-Stratiotetum } \\
\text { (Langendonck 1935) Westhoff } \\
\text { 1945) }\end{array}$ \\
\hline 5. & $\begin{array}{l}\text { Hydrocharitetum morsus-ranae } \\
\text { van Lang } 1935\end{array}$ & $\begin{array}{l}\text { Lemno-Hydrocharitetum } \\
\text { (Oberdorfer 1957) Passarge } 1978\end{array}$ \\
\hline 6. & Groups of Utricularia & $\begin{array}{l}\text { Lemno-Utricularietum vulgaris } \\
\text { Soó } 1928\end{array}$ \\
\hline 7. & $\begin{array}{l}\text { Nymphoidetum peltatae Allorge } \\
1922\end{array}$ & $\begin{array}{l}\text { Nymphoidetum peltatae (Allorge } \\
\text { 1922) Bellot } 1951\end{array}$ \\
\hline 8. & $\begin{array}{l}\text { Nymphaeetum albo-luteae } \\
\text { Nowinski } 1928\end{array}$ & $\begin{array}{l}\text { Nymphaeetum albae Oberdorfer } \\
\text { 1957; Nymphaeetum albo-luteae } \\
1928\end{array}$ \\
\hline 9. & $\begin{array}{l}\text { Trapetum natantis Müller et Görs } \\
1960\end{array}$ & $\begin{array}{l}\text { Trapetum natantis Müller and Görs } \\
1960\end{array}$ \\
\hline 10. & $\begin{array}{l}\text { Myriophylleto-Potametum lucentis } \\
\text { Soó } 1934\end{array}$ & - \\
\hline 11. & $\begin{array}{l}\text { Potametum perfoliate Koch W. } \\
\text { 1926/ em. Passarge } 1964\end{array}$ & $\begin{array}{l}\text { Potamogetonetum perfoliati Koch } \\
1926 \text { em. Passarge } 1964\end{array}$ \\
\hline 12. & Potametum crispi & Potamogetonetum crispi Soó 1927 \\
\hline 13. & $\begin{array}{l}\text { Potametum pectinati Carstensen } \\
1955\end{array}$ & $\begin{array}{l}\text { Potamogetonetum pectinati } \\
\text { Carstensen } 1955\end{array}$ \\
\hline 14. & Potametum lucentis Hueck 1931 & $\begin{array}{l}\text { Potamogetonetum lucentis, only } \\
\text { very small patches }\end{array}$ \\
\hline 15. & - & $\begin{array}{l}\text { Elodeetum nutallii Ciocârlan et al. } \\
1997\end{array}$ \\
\hline 16. & - & $\begin{array}{l}\text { Potamogetonetum trichoidis Freit } \\
\text { et al. } 1956\end{array}$ \\
\hline
\end{tabular}




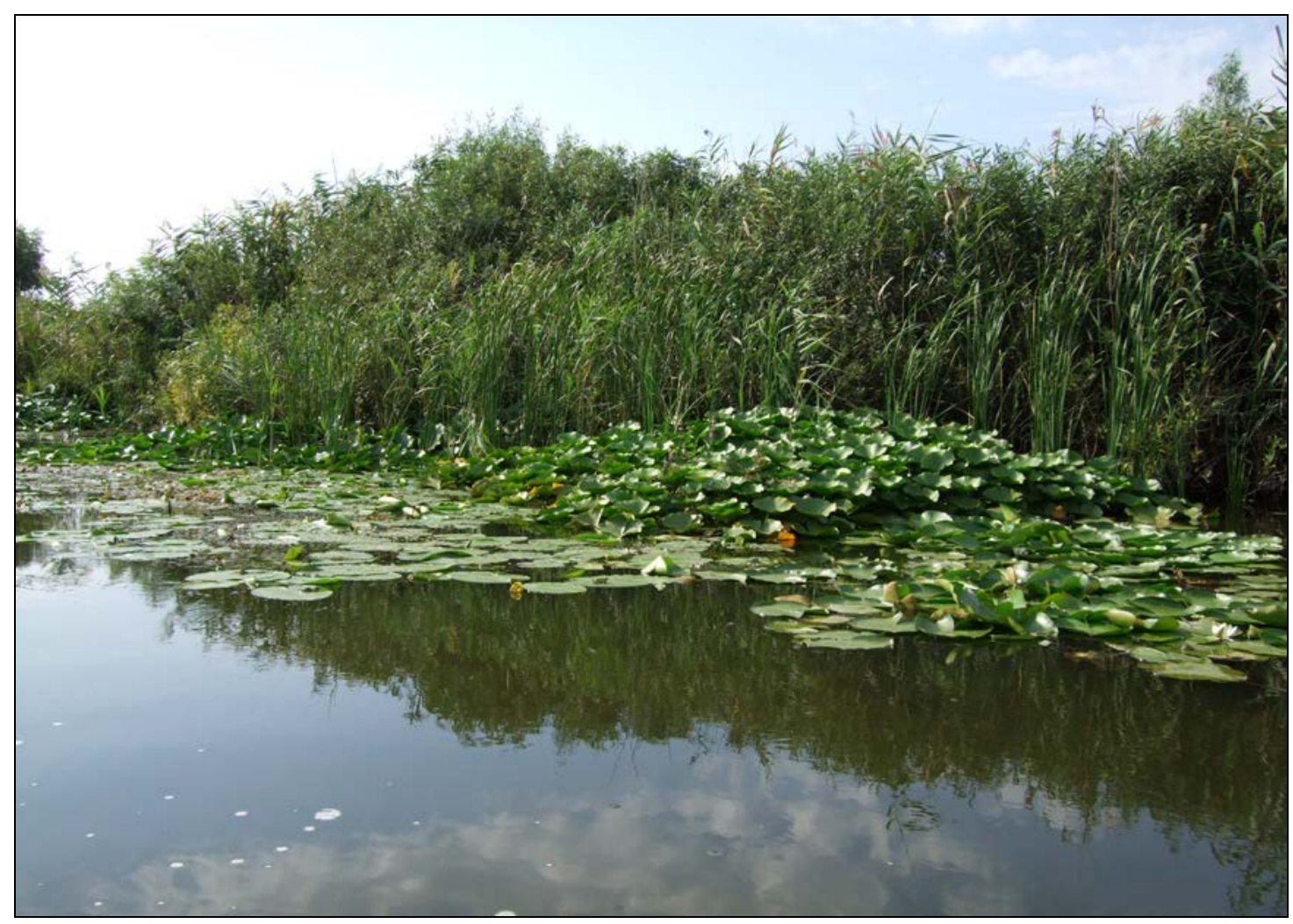

Figure 7: Belt of abundant Nymphaea alba along the reeds in the Eracle Channel.

\section{CONCLUSIONS}

The occurrence and repartition of water macrophyte communities is in strong relation to the hydrological regime, water body types and their quality. The larger canals such as the Litcov and Uzlina canals shelter typical communities for running waters with the dominance of Potamogeton nodosus, accompanied by some other species such as Potamogeton perfoliatus, $P$. pectinatus and Trapa natans, occurring also in the lakes of the Danube Delta. The Perivolovca Canal and smaller channels of various lengths are characterised more by species which occur predominantly in standing waters. The macrophyte communities have in general a eutrophic character, whereas some smaller lakes more isolated in the reed-beds present a mesotrophic character, but a shifting of communities to waters with a eutrophic character is clearly visible. The most frequent communities in the lakes are those of Nuphar lutea and Nymphaea alba, the last occurring frequently as a belt in contact with the reeds (Fig. 7). Trapa natans occurs as well over a large area in the lakes and is often situated near the mouth of channels with water currents. In larger lakes with different niches on the shore a larger diversity of communities can be observed. Pondweed species such as Potamogeton pectinatus and $P$. trichoides occur in the open large lakes of eutrophic character.

The lakes with former high abundance of Characeae change their character as they disappear due to eutrophication and growing turbidity by plankton and fast-growing macrophytes producing high organic matter. The changes in water quality are also responsible for the reduction of the occurrence of Potamogeton lucens, which has been observed only in some small patches in the lakes. Even if there are many changes in dominance and abundance of macrophytes conditioned by short term variations of the hydrological regime long term changes became visible also taking into account the changes induced by human impact. 


\section{ACKNOWLEDGEMENTS}

In grateful remembrance of RNDr. Stepán Husák († 25.10.2014), Trebon, Department of the Institute of Botany of the Academy of Science of Czech Republic, Section of Plant Ecology I, would like to mention his valuable help in the determination of Characeae and revision of some determined small-leaved pondweed (Potamogeton) species. The valuable scientific discussions with him in Trebon on the way back from the Danube Delta to Germany related to water macrophytes remain a personal scientific gain. At the same time I would like to express my thanks also to Dr. Castella, University of Genf, Switzerland, for determination of some Characeae species of the Danube Delta; and not at least to the staff of Danube Delta National Institute Tulcea, in particular to Mr. Covaliov and Mr. Tudor from the research team for joint field activities for sampling aquatic macrophytes.

\section{REFERENCES}

1. Botzan M., 1984 - Apele în viaţa poporului român/The waters in the life of Romanian people, Edit. Ceres, Bucureşti, 410. (in Romanian)

2. Braun-Blanquet J., 1964 - Pflanzensoziologie, 3, Auflage, Springer Verlag Wien, 865. (in German)

3. Ciocârlan V., 1994 - Flora Deltei Dunării, Cormophyta, Edit. Ceres, Bucureşti, 115. (in Romanian)

4. Ciocârlan V., 2009 - Flora ilustrată a României, Pteridophyta et Spermatophyta, Edit. Ceres, Bucureşti, 1141. (in Romanian)

5. Ciocârlan V., Sârbu I., Ştefan N. and Tudor M., 1998 - Elodea nutallii (Planchon) Saint John o specie nouă în flora României, Buletinul Grădinii Botanice „Anastasie Fătu”, Iaşi, 6, 1, 215231. (in Romanian)

6. Covaliov S., van Geest G., Hanganu J., Hulea O., Török L. and Coops H., 2003 - Seasonality of macrophyte dominance in flood-pulsed lakes of the Danube, Hydrobiologia, 506-509, 651656, Kluwer Academic Publishers.

7. Dihoru G. and Negrean G., 2009 - Cartea Roșie a plantelor vasculare din România, Edit. Academiei Române, București, 630. (in Romanian)

8. Doroftei M and Covaliov S., 2003 - „Manual de ... Delta Dunării”, Ghid pentru personalul de teren al Administraţiei Rezervaţiei Biosferei Delta Dunării şi gărzii de mediu, Edit. Centrul de informare tehnologică Delta Dunării, Tulcea, 482. (in Romanian)

9. $\quad$ Ellenberg H., Weber H. E., Düll R., Wirth V. and Werner W., 2002 - Zeigerwerte von Pflanzen in Mitteleuropa/Indicator values of plants in Central Europe, Scripta Geobotanica, 18, 264, Erich Goeltze K. G., Göttingen. (in German)

10. EUR28, 2013 - Interpretation Manual of the European Union habitats, European Commission D. G. Environment, 144.

11. Gâştescu P. and Ştiucă R. (eds), 2008 - Delta Dunării. Rezervaţie a Biosferei, Edit. CD PRESS, Bucureşti, 400. (in Romanian with English explanations on figures, tables and maps)

12. Gâştescu P. and Driga B., 1989 - Der Wasserumlauf im Donaudelta - ökologische und wirtschaftliche Bedeutung, Revue Roumaine de Géologie, Géophysique et Géographie, Géographie, 33, 37-41, Edit. Academiei Române, Bucureşti. (in German)

13. Godeanu M., 1976 - Consideraţii generale asupra principalelor asociaţii acvative şi palustre din Delta Dunării în condiţii naturale şi amenajate, Peuce, V, 57-99, Muzeul Deltei Dunării Tulcea. (in Romanian)

14. Godeanu M. and Ionescu-Ţeculescu V., 1971 - Influența chimismului apei și solului asupra dezvoltării unor characee din Delta Dunării, Peuce, I, Seria Științele Naturii, 261-267, Tulcea. (in Romanian) 
15. Hanganu J. and Constantinescu A., 2008 - Challenge for ecological reconstruction of the largest agricultural polder in the Danube Delta (Romania), Transylvanian Review of Systematical and Ecological Research, 6, The Wetlands Diversity, 177-184.

16. Krause W., 1997 - Charales (Charophyceae), Reihe: Süßwasserflora von Mitteleuropa, 18, 202, Gustav Fischer Jena Stuttgart Lübeck Ulm. (in German)

17. Munteanu I. and Curelariu G., 1996 - Tematic map of the Danube Delta, 4, Drainage and inundability, 1:175.000, Edit. By Institute for Soil and Agrochemical Research, Bucharest, Romania ICPDD Tulcea, Romania, RIZA Lelystad, The Netherlands.

18. Neagu-Godeanu M., 1973 - Fitocenozele acvatice şi palustre din delta Dunării în condiţii naturale şi amenajate, Rezumatul tezei de doctorat, Institutul Central de Bioklogie, Institutul de Științe Biologice București, 53. (in Romanian)

19. Neagu-Godeanu M., 1975 - Fitocenozele acvatice şi palustre din delta Dunării în condiţii naturale şi amenajate. Institutul Central de Biologie, Institutul de Ştiinţe Biologice Bucureşti, Teză de doctorat, I, 307, II, tables, graphics and maps. (in Romanian)

20. Oosterberg W. and Staraş M. (eds), 2000 - Ecological gradients in the Danube Delta, Present state and man induced changes, RIZA rapport 2000.015, 95-109, Lelystad. (in English)

21. Oberdorfer E., 2001 - Pflanzensoziologische Exkursionsflora für Deutschland und angrenzende Gebiete, VerlaG Eugen Ulmer, Stuttgart, 1051. (in German)

22. Oțel V. (ed.), 2000 - The red list of plant and animal species from the Danube Delta Biosphere Reserve Romania, Fundația Aves/Aves Foundation, 132. (in Romanian and English)

23. Sanda V., Popescu A., Doltu M. I. and Doniţă N., 1983 - Caracterizarea ecologică şi fitocenologică a speciilor spontane din flora României, Studii şi Comunicări Ştiinţe Naturale, 25, 1-126, Supliment. (in Romanian)

24. Sanda V., Öllerer K. And Burescu P., 2008 - Fitocenozle din România, Sintaxonomie, structură, dinamica și evoluție, Ars Docendi, Universitatea București, 570. (in Romanian)

25. Sârbu I., Ştefan N. and Oprea A., 2013 - Plante vasculare din România, Determinator ilustrat de teren, Edit. Victor B. Victor, Bucureşti, 1231. (in Romanian)

26. Schneider E. 2009 - Aquatic macrophytes in the Danube Delta - indicators for water quality and habitat parameters, Studia Universitatis Babeş-Bolyai, Biologie, LIV, 1, 21-31.

27. Schneider E. 2014 - Aspects of Wetland Habitat Restoration and Monitoring in the Danube Delta: Water Macrophytes as Quality Indicators in Evaluation Processes, Acta Zoologica Bulgarica, Supplement 7, 97-102, IAD 40th Anniversary Conference, Bulgarian Academy of Sciences Sofia, ISSN 0324-0770.

28. Schneider E., Tudor M. and Staraş M., 2008 - Evolution of Babina Polder after restoration works, WWF Germany and Danube Delta National Institute for Research and Development, 81.

29. Strat D., 2015 - The demographic success of Marsilea quadrifolia L. in a man-made water body from Danube Delta Biosphere Reservation, Transylvanian Review of Systematical and Ecological Research, 17.1, The Wetlands Diversity, 121-132. 